Vol. 1 No. 2 September 2021 e-ISSN : 2797-3344 P-ISSN : 2797-3336

\title{
UPAYA PENINGKATAN MINAT BELAJAR DAN PRESTASI BELAJAR FISIKA MELALUI MODEL PEMBELAJARAN INKUIRI PADA SISWA KELAS XII SMAN 9 KOTA JAMBI TAHUN PELAJARAN 2018-2019
}

\author{
HELNOVIA \\ SMA Negeri 9 Kota Jambi Provinsi Jambi \\ Email : helnolviabayu@gmail.com
}

\begin{abstract}
ABSTRAK
Tujuan penelitian adalah meningkatkan minat dan prestasi belajar fisika siswa kelas XII IPA 2 SMA Negeri 9 Kota Jambi Tahun Pelajaran 2018-2019. Maka pendekatan yang dilakukan adalah menerapkan model pembelajaran Inkuiti untuk mencapai tujuan tersebut. Keberhasilan penelitian ditentukan bahwa apabila minat siswa terhadap pelajaran fisika secara klasikal sangat tinggi, dan ketuntasan prestasi belajar fisika secara klasikal mencapai sekurang-kurangnya 85 $\%$ dari seluruh siswa. Penelitian ini dilakukan sesuai dengan tahapan penelitian tindakan kelas, subyek penelitian 35 siswa yang terdiri atas 15 siswa laki-laki dan 20 siswa perempuan. Cara pengambilan data yaitu angket minat belajar fisika dan tes prestasi belajar siswa, dengan analisis porsentasi. Hasil penelitian diperoleh minat belajar fisika pra siklus $65 \%$ kategori cukup tinggi, siklus I 79\% kategori tinggi, dan siklus II 81\% kategori sangat tinggi. Sedangkan prestasi belajar siswa diperoleh ketuntasan klasikal pra siklus $11 \%$, siklus I 20\%, dan siklus II $89 \%$. Berdasarkan hasil ini baik minat maupun prestasi belajar mengalami peningkatan bahkan mencapai indikator keberhasilan.
\end{abstract}

Kata Kunci: Inkuiri, minat belajar, prestasi belajar.

\section{PENDAHULUAN}

Memasuki abad ke-21 ini, kualitas kehidupan bangsa ditentukan oleh faktor pendidikan. Peran pendidikan sangat penting untuk menciptakan kehidupan bangsa yang cerdas, damai, dan demokratis. Menurut Jean Pieget pendidikan sebagai penghubung dua sisi, disatu sisi individu yang sedang tumbuh dan disisi lain nilai sosial, intelektual, dan moral yang menjadi tanggung jawab pendidik untuk mendorong individu tersebut (Sagala, 2011:1). Seperti sekarang ini, di Indonesia kebanyakan sekolah telah menggunakan kurikulum baru yaitu kurikulum 2013. Di dalam kurikulum 2013 ini terdapat beberapa prinsip pembelajaran yang diharapkan menunjang mutu pendidikan Indonesia. Diantara prinsip-prinsip pada kurikulum 2013 yaitu mendorong siswa menjadi peserta didik yang aktif, jika biasanya kegiatan pembelajaran dimulai dengan penyampaian informasi dari guru, maka kurikulum 2013 ini dimulai dengan siswa mengamati fenomena atau peristiwa tertentu sehingga guru dapat membangkitkan rasa ingin tahu siswa terhadap fenomena atau peristiwa tersebut. Sehingga pada kurikulum 2013 ini guru hanya bertindak sebagai motivator dan fasilitator, namun pada akhir kegiatan inti guru juga memberikan penjelasan penyempurnaan dari kegiatan siswa (Parasamya, dkk, 2017).

Proses perolehan pengetahuan akan terjadi apabila guru dapat menciptakan suatu kondisi pembelajaran yang sesuai dengan karakteristik pembelajaran IPA dan memperhatikan perspektif siswa. Pembelajaran yang demikian merupakan pembelajaran yang mengutamakan keaktifan siswa. Apabila guru berhasil menciptakan suasana yang dapat menyebabkan siswa terminat aktif dalam belajar, maka akan memungkinkan terjadi peningkatan hasil belajar. Pembelajaran fisika merupakan proses pembelajaran yang melibatkan siswa dalam mempelajari alam dan gejala-gejalanya melalui serangkaian proses ilmiah yang dibangun atas dasar sikap ilmiah untuk memperoleh dan memproses pengetahuan, keterampilan dan sikap agar dapat mencapai tujuan belajar tertentu. Pembelajaran fisika menuntut kemampuan siswa untuk pemahaman konsep dan pemecahan masalah (Putri, dkk, 2017). Setiyawan, dkk (2013) menjelasakan bahwa fisika merupakan produk dan proses yang dapat diartikan bahwa dalam pembelajaran fisika subyek belajar (siswa) harus dilibatkan secara fisik maupun mental dalam pemecahan masalah-masalah. Dalam proses pembelajaran fisika, siswa tidak hanya membaca, 
mendengarkan, dan mengerjakan apa yang diberikan oleh guru, melainkan siswa hendaknya diberi kesempatan untuk membuktikan kebenaran dari teori yang ada dan diberi kesempatan untuk menemukan sesuatu yang baru dengan cara berdiskusi, melakukan penyelidikan, dan bekerja sama. Fisika merupakan bidang studi yang tidak menjadi favorit bagi siswa.

Setiap siswa mempunyai pandangan yang berbeda tentang pelajaran fisika. Ada yang memandang fisika sebagai mata pelajaran yang menyenangkan dan ada juga yang memandang fisika sebagai pelajaran yang sulit. Bagi yang menganggap fisika menyenangkan maka akan tumbuh minat dalam diri peserta didik untuk mempelajari fisika dan optimis dalam menyelesaikan masalah-masalah yang bersifat menantang dalam pelajaran fisika. Sebaliknya, bagi yang menganggap fisika sebagai pelajaran yang sulit, maka peserta didik tersebut akan bersikap pesimis dalam menyelesaikan masalah fisika dan kurang menyukai pelajaran fisika. Sikap-sikap tersebut tentunya akan mempengaruhi hasil dan prestasi belajar yang siswa capai dalam belajar (Astuti, 2015). Beberapa faktor yang mempengaruhi keberhasilan siswa dalam belajar fisika, diantaranya faktor internal yang meliputi kemampuan awal, tingkat kecerdasan, minat belajar, kebiasaan belajar, kecemasan belajar, minat belajar, dan sebagainya. Sedangkan faktor eksternal meliputi lingkungan keluarga, lingkungan sekolah, lingkungan masyarakat, keadaan sosial ekonomi, dan sebagainya (Zulkarnain, 2020).

Mata pelajaran fisika bagi siswa-siswi SMA Negeri 9 Kota Jambi termasuk mata pelajaran yang paling sulit untuk dipelajari. Setiap ada mata pelajaran fisika siswa-siswa merasa ada beban yang berat dalam pikirannya. Pada saat bel berbunyi menandakan waktu pelajaran telah usai, siswa-siswa merasakan bahagia sekali pelajaran fisika selesai, ia merasa lega lepas dari beban fisika yang tidak mengerti-mengerti. Ini menunjukkan adanya indikator kurangnya minat dan minat belajar mata pelajaran fisika, sehingga mempengaruhi pencapaian hasil dan prestasi belajar siswa pada mata pelajaran fisika yang masih rendah.

Menurut Putra (2019) pendidikan berarti menghasilkan dan mencipta, meskipun suatu penciptaan itu dibatasi oleh perbandingan sangat dipengaruhi oleh banyak faktor, salah satunya adalah minat anak dalam belajar. Minat memiliki peranan yang sangat penting dalam kehidupan siswa dan mempunyai dampak yang besar terhadap sikap dan perilaku. Siswa yang berminat terhadap kegiatan pembelajaran akan berusaha lebih keras dibandingkan siswa yang tidak berminat. Siswa akan malas belajar dan tidak tertarik pada suatu pelajaran jika tidak memiliki minat di dalamnya. sebaliknya pelajaran yang menarik minat siswa, lebih akan mendapatkan kepuasan dari pelajaran itu. secara individu maupun berkelompok.

Minat belajar sangat besar pengaruhnya terhadap hasil belajar, karena apabila bahan pelajaran yang dipelajari tidak sesuai dengan minat, siswa tidak siswa yang kurang berminat dalam belajar. Dalam belajar diperlukan suatu pemusatan perhatian agarapa yang dipelajari dapat dipahami. Dalam meningkatkan minat belajar siswa, proses pembelajaran dapat dilakukand engan penciptaan yang lain, pendidikan sebagai penghubung dua sisi, di satu sisi individu yang sedang tumbuh dan disisi lain nilai sosial, intelektual, dan moral yang akhirnya menjadi tanggung jawabpendidik untuk mendorong individu tersebut. Setiap orangtua yang menyekolahkan anaknya menginginkan anaknya meraih nilai yang baik. Namun untuk mencapai hal itu bukanlah suatu hal yang mudah (Astalini, dkk, 2018).

Minat dapat dibangkitkan dengan cara menghubungkan materi pelajaran dengan suatu berita sensasional yang sudah diketahui kebanyakan siswa. Minat belajar dalam diri siswa harus dipupuk secara terus menerus sehingga akan semakin meningkat didalam diri siswa (hartuti, 2015). Namun, seiring dengan kemajuan teknologi yang semakin pesat dapat mengakibatkan dampak buruk pada minat belajar siswa. Banyak faktor yang dapat menurunkan minat belajar dalam diri siswa seperti, banyaknya jenis hiburan, games, dan tayangan TV yang dapat mengalihkan perhatian siswa dari buku pelajaran. Dengan minat belajar yang tinggi siswa dapat memperoleh pengetahuan dan wawasan serta hasil belajar yang baik. Dalam pembelajaran guru harus melihat kondisi siswa, karena kondisi siswa sangat penting untuk diperhatikan. Kondisi siswa yang sangat penting adalah bagaimana minatnya dalam mata pelajaran. Siswa yang berminat akan lebih perhatian dan akan lebih ingin tahu terhadap mata pelajaran yang 
dipelajarinya. Minat yang kuat akan menimbulkan usaha yang gigih dan tidak putus asa dalam menghadapi tantangan (Mahyudi, 2012).

M. Dalyono dalam (Mulyani, 2013) menyatakan bahwa "belajar merupakan suatu kegiatan untuk mengadakan perubahan di dalam diri seseorang yaitu: perubahan tingkah laku, sikap, kebiasaan, ilmu pengetahuan, keterampilan dan sebagainya". Perubahan-perubahan ini merupakan perbuata belajar yang diinginkan, karena itu dapat dikatakan bahwa perubahan yang diinginkan akan menjadi tujuan dari proses pembelajaran. Untuk mencapai tujuan pembelajaran tersebut, maka seseorang harus memiliki kesiapan. Kesiapan individu sebagai seorang siswa dalam belajar akan menentukan kualitas proses dan prestasi belajar siswa.

Prestasi belajar diartikan sebagai ukuran pengetahuan yang didapat dari pendidikan formal dan ditunjukkan melalui nilai tes (Lawrence \& Vimala, 2012). Selaras dengan pendapat tersebut, Goods dalam Anees (2013) mendefinisikan prestasi belajar sebagai pengetahuan yang dicapai maupun keterampilan yang dikembangkan pada berbagai mata pelajaran di sekolah yang biasanya ditentukan oleh nilai ujian maupun dengan nilai yang diberikan oleh guru, atau keduanya. Kpolovie, Joe, dan Okoto (2014) menambahkan bahwa prestasi belajar merupakan kemampuan siswa untuk belajar dapat dikatakan sebagai hasil yang diperoleh dari kegiatan pembelajaran di sekolah yang bersifat kognitif dan biasanya ditentukan melalui pengukuran dan penilaian.

Prestasi belajar merefleksikan penguasaan terhadap mata pelajaran yang ditentukan lewat nilai atau angka yang diberikan guru. Prestasi belajar penting untuk diteliti mengingat prestasi belajar dapat digunakan untuk (1) mengetahui tingkat penguasaan siswa terhadap materi pelajaran yang telah disampaikan, (2) mengetahui kecakapan, minat, bakat, minat, dan sikap siswa terhadap program pembelajaran, (3) mengetahui tingkat kemajuan dan kesesuaian hasil belajar atau prestasi belajar siswa dengan standar kompetensi dan kompetensi dasar yang telah ditetapkan, (4) mendiagnosiskeunggulan dan kelemahan siswa dalam mengikuti kegiatan pembelajaran, (5) seleksi yaitu memilih dan menentukan siswa yang sesuai dengan jenis pendidikan tertentu, (6) menentukan kenaikan kelas, serta (7) menempatkan siswa sesuai dengan potensi yang dimilikinya (Syarif, 2012).

Untuk meningkatkan minat belajar dan prestasi belajar siswa, maka pada penelitian ini dilaksanakan model pembelajaran inkuiri, untuk memperbaharui proses belajar siswa. Penggunaan model inkuiri akan menciptakan kegiatan pembelajaran yang lebih menyenangkan dan akhirnya berpengaruh pada pemahaman konsep yang ditemukan. Pada prinsipnya tujuan pengajaran inkuiri membantu siswa bagaimana merumuskan pertanyaan, mencari jawaban atau pemecahan untuk memuaskan keingintahuannya dan untuk membantu teori dan gagasannya tentang dunia. Lebih jauh lagi dikatakan bahwa pembelajaran inkuiri bertujuan untuk mengembangkan tingkat berpikir dan juga keterampilan berpikir kritis (Juniati, dkk, 2017). Penerapan model ini sangat penting diterapkan dalam upaya meningkatkan mutu pendidikan.

\section{METODE PENELITIAN}

Penelitian ini merupakan Penelitian Tindakan Kelas (PTK) atau sering disebut dengan istilah dalam bahasa Inggris Classroom Action Research. Penelitian ini dilakukan sebanyak 2 siklus yaitu siklus I dan siklus II. Kedua siklus tersebut menerapkan pendekatan model pembelajaran Inkuiri. Materi yang diajarkan yaitu siklus I, Radiasi Benda Hitam dan Teori Atom, sedangkan siklus II, Fisika Inti dan Radioaktifitas.

Penelitian tindakan ini akan dilaksanakan dalam dua siklus, dengan tiap siklus terdiri atas 4 tahapan yaitu: Planning (perencanaan), Action (tindakan), Observation (pengamatan), Reflection (refleksi). Adapun jenis data yang digunakan dalam penelitian ini adalah data kualitatif dan data kuantitatif yang terdiri dari: a) Data minat belajar siswa. b) Data prestasi hasil belajar fisika siswa. Metode pengumpulan data yang digunakan dalam penelitian ini adalah angket minat belajar, dan tes prestasi hasil belajar. Instrument angket berjumlah 10 pernyataan dengan pilihan yang dibuat 4 kategori yaitu sangat setuju, setuju, cukup setuju, dan tidak setuju, skor maksimal yang dicapai oleh siswa adalah 10 x $4=40$ dan skor minimal adalah 
$10 \times 1=10$. Untuk mengetahui persentasi siswa dari data angket yang diperoleh dengan menggunakan rumus porsentase. Selanjutnya data yang diperoleh dianalisis secara deskriptif kualitatif dengan menghitung ketuntasan individu dan prosentase ketuntasan klasikal. Ketuntasan belajar individu untuk mengetahui prestasi hasil belajar setiap siswa. Dengan indikator keberhasilan siswa dikatakan tuntas belajar jika siswa memperoleh nilai sesuai dengan Kriteria Ketuntasan Minimal (KKM) 70.

\section{HASIL DAN PEMBAHASAN}

Di bawah ini disajikan tabel analisis angket minat belajar fisika siswa kelas XII IPA 2 SMA Negeri 9 Kota Jambi Tahun Pelajaran 2018-2019:

Tabel 1: Minat siswa pada pembelajaran fisika Siswa kelas XII IPA 2

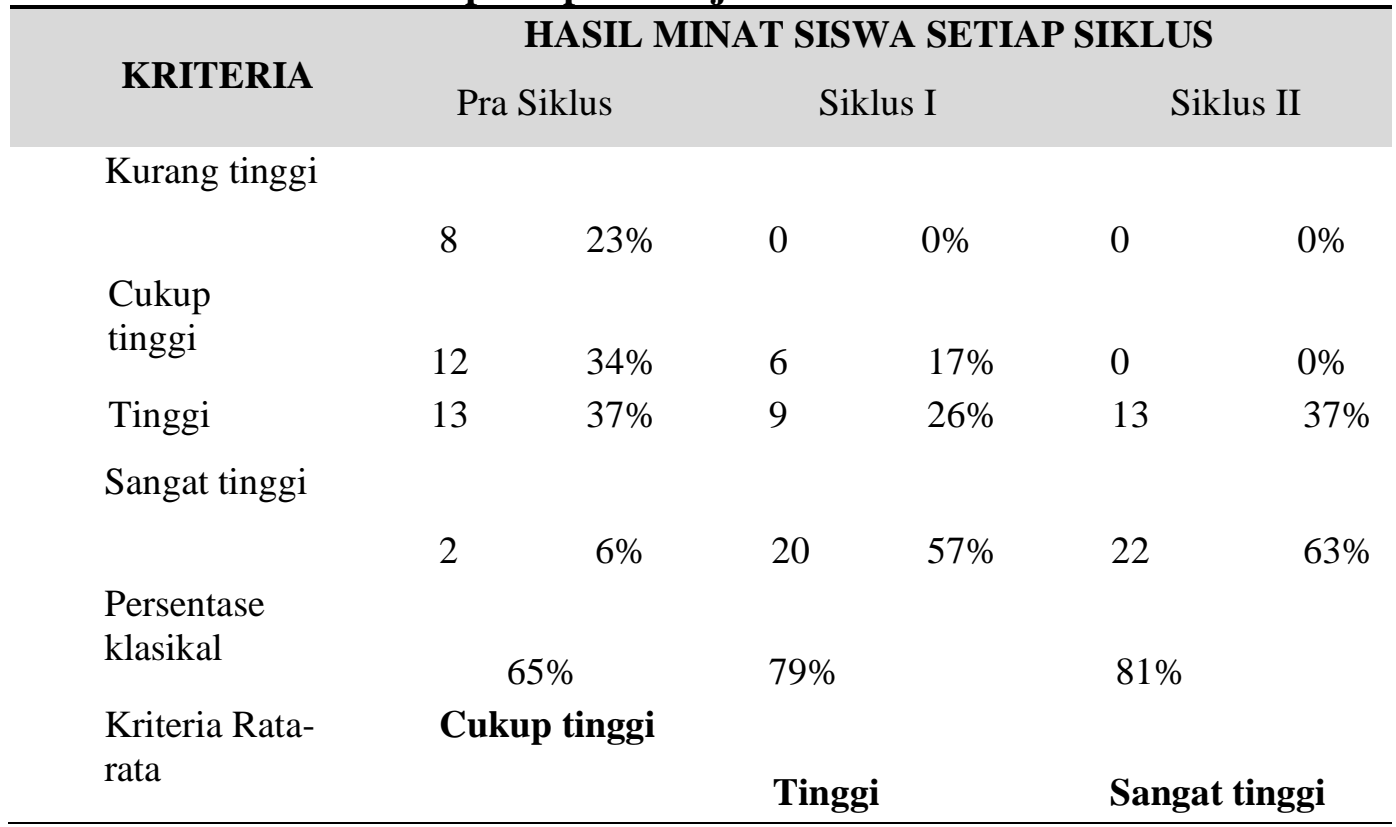

Tabel 2: Prestasi belajar fisika Siswa kelas XII IPA 2

\begin{tabular}{lccc} 
& \multicolumn{3}{c}{ HASIL BELAJAR SISWA } \\
& Pra Siklus & Siklus I & Siklus II \\
Nilai terendah & 10 & 12 & 44 \\
Nilai tertinggi & 75 & 88 & 100 \\
Rata-rata & 45 & 55.1 & 81.5 \\
Siswa tidak tuntas & 31 & 28 & 4 \\
$\quad$ Siswa tuntas & 4 & 7 & 31 \\
Persentase klasikal & $11 \%$ & $20 \%$ & $89 \%$ \\
\hline
\end{tabular}

Dikatakan tuntas secara klasikal apabila sekurang-kurangnya $85 \%$ dari jumlah seluruh siswa di kelas tuntas.

\section{Pra Siklus}

Berdasarkan hasil angket pada pra siklus telah diketahui bahwa minat belajar siswa terhadap mata pelajaran fisika cukup tinggi hal ini didasarkan pada persentase klasikal mencapai $65 \%$. Dari 35 siswa, minat siswa pada kriteria kurang tinggi ada di angka 23\%, cukup tinggi $34 \%$, tinggi $37 \%$, dan sangat tinggi $6 \%$. Hal ini disebabkan karena pada kondisi ini pembelajaran dilakukan secara konvensional atau ceramah. Bagi siswa yang kurang kreatif 
biasanya metode ini sangat ideal buat mereka, namun sebaliknya bagi yang kreatif metode ini biasanya sangat membosankan. Sehingga minat mereka berkurang buktinya dari 35 siswa yang ada hanya 2 siswa saja yang sangat tinggi minat belajar fisikanya.

Hasil ulangan dari pembelajaran sebelumnya menunjukkan bahwa rata-rata nilai fisika hanya 45 , yang mencapai nilai ketuntasan 4 siswa dan yang tidak tuntas ada 31 siswa, sehingga pada pra siklus ini persentase klasikal hanya $11 \%$. Hal ini berbanding lurus dengan minat belajar fisika. Maka upaya yang dilakukan dengan diskusi dan presentasi pada kegiatan pembelajaran.

\section{Siklus I}

Berdasarkan hasil angket yang diberikan pada siswa pada setelah melakukan pembelajaran siklus I telah diketahui bahwa minat belajar siswa terhadap mata pelajaran fisika mencapai kriteria tinggi hal ini didasarkan pada persentase klasikal mencapai 79\%. Angka ini berada diantara 66-79 dengan kriteria tinggi. Dari 35 siswa, minat siswa kurang tinggi tidak ada lagi, cukup tinggi $17 \%$, tinggi $26 \%$, dan sangat tinggi $57 \%$. Jika dibandingkan dengan prasiklus maka minat belajar siswa terhadap mata pelajaran fisika pada siklus I terjadi peningkatan. Hal ini dapat dilihat pada tabel minat belajar dari kriteria cukup tinggi sebelum dilakukan pendekatan presentasi dan diskusi meningkat pada kriteria tinggi pada siklus I. Dengan dilakukannya pendekatan presentasi dan diskusi maka pembelajaran tidak lagi sematamata dari guru ke siswa atau pembelajaran didominasi oleh guru, melainkan pembelajaran didominasi oleh siswa. Artinya pembelajaran ini menuntut kreativitas dan aktivitas siswa untuk mencari literature yang berhubungan dengan konsep yang sedang mereka pelajari, peran guru hanya memfasilitasi dan memberikan penilaian terhadap hasil diskusi dan presentasi.

Hasil test setelah pembelajaran pada siklus I menunjukkan bahwa rata-rata nilai fisika 55,1 , yang terdiri atas siswa tuntas 7 orang dan tidak tuntas 28 orang. Sehingga pada siklus ini persentase klasikal 20\%. Hasil ini menunjukkan bahwa ketika pembelajaran menerapkan model pembelajaran Inkuiri dapat meningkatkan hasil belajar fisika. Ketika minat belajar fisika meningkat maka prestasi belajar meningkat pula.

Dari hasil yang diperoleh pada siklus I secara umum baik minat belajar maupun prestasi belajar fisika pada kelas XII IPA 2 mengalami peningkatan. Hal ini disebabkan karena siswa aktif mencari informasi sendiri pada pembelajaran tersebut, sehingga mereka memahami materi yang dipelajari.

Berdasarkan hasil refleksi dari siklus I maka pembelajaran masih perlu dilanjutkan pada siklus II, mengingat hasil siklus I belum mencapai indikator keberhasilan. Walaupun minat dan prestasi belajar telah mengalami peningkatan, namun penelitian belum dianggap berhasil. Sehingga perlu dilakukan perbaikan proses pembelajaran pada siklus II.

\section{Siklus II}

Pada siklus II materi yang disampaikan adalah Fisika Inti dan Radioaktifitas. Tindakan pada siklus II tidak jauh beda dengan pembelajaran yang dilakukan pada siklus I. Sama seperti pembelajaran siklus I, pada siklus II kelompok siswa diperintahkan untuk mepresentasikan inti materi yang didiskusikan. Salah satu siswa menjadi moderator pada proses presentasi dan diskusi. Sebagai ketua kelompok mempresentasikan materi dengan menggunakan proyektor slide. Pada siklus II dilakukan sebanyak 3 kali pertemuan, untuk 3 kelompok.

Berdasarkan hasil angket yang diberikan pada siswa pada setelah melakukan pembelajaran siklus II telah diketahui bahwa minat belajar siswa terhadap mata pelajaran fisika mencapai kriteria sangat tinggi hal ini didasarkan pada persentase klasikal mencapai $81 \%$. Angka ini berada diantara 80 - 100 dengan kriteria sangat tinggi. Dari 35 siswa, minat siswa kurang tinggi dan cukup tinggi tidak ada lagi, tinggi 37\%, dan sangat tinggi 63\%. Jika dibandingkan dengan siklus I maka minat belajar siswa terhadap mata pelajaran fisika pada siklus II terjadi peningkatan. Hal ini dapat dilihat pada tabel minat belajar dari kriteria tinggi pada siklus I meningkat pada kriteria sangat tinggi pada siklus II. Berdasarkan indikator 
keberhasilan penelitian dikatakan berhasil apabila kriteria secara klasikal minat belajar fisika sangat tinggi, maka penelitian ini dianggap berhasil karena dengan pendekatan model pembelajaran Inkuiri dapat meningkatkan minat belajar fisika.

Hasil test setelah pembelajaran pada siklus II menunjukkan bahwa rata-rata nilai fisika mencapai 81,5 , yang terdiri atas siswa tuntas 31 orang dan tidak tuntas 4 orang. Sehingga pada siklus ini persentase ketuntasan klasikal 85\%. Hasil ini menunjukkan bahwa ketika pembelajaran menerapkan pendekatan model pembelajaran Inkuiri dapat meningkatkan prestasi hasil belajar fisika. Ketika minat belajar fisika meningkat maka prestasi belajar meningkat pula.

Dari hasil yang diperoleh pada siklus I secara umum baik minat belajar maupun prestasi belajar fisika pada kelas XII IPA 2 mengalami peningkatan. Hal ini disebabkan karena siswa aktif mencari informasi sendiri pada pembelajaran tersebut, sehingga mereka memahami materi yang dipelajari. Pada pendekatan model pembelajaran Inkuiri siswa terlebih dahulu melakukan presentasi yang dilakukan oleh salah satu anggota kelompok yang mereka anggap bisa. Presentasi dimaksudkan untuk memaparkan secara umum materi yang sedang didiskusikan. Selanjutnya kelompok yang lain mengajukan pertanyaan sesuai dengan materi yang disampaikan. Berdasarkan indikator keberhasilan diatas penelitian berhasil apabila porsentase ketuntasan secara klasikal mencapai $85 \%$. Mengingat hasil yang diperoleh pada siklus II mencapai $89 \%$ maka penelitian ini dianggap berhasil.

\section{KESIMPULAN}

Kesimpulan yang diperoleh berdasarkan latar belakang masalah, rumusan masalah, dan hasil analisis data: melalui pembelajaran model inkuiri, dapat disimpulkan bahwa model pembelajaran Inkuiri dapat meningkatkan minat dan prestasi belajar fisika pada siswa kelas XII IPA 2 SMA Negeri 9 Kota Jambi Tahun Pelajaran 2018-2019, dengan capaian secara klasikal $81 \%$ untuk minat belajar pada kriteria sangat tinggi dan ketuntasan secara klasikal prestasi belajar $89 \%$. Minat belajar fisika sangat tinggi dan prestasi belajar meningkat dengan penggunaan model pembelajaran Inkuiri.

\section{DAFTAR PUSTAKA}

Anees, A. (2013). A study of academic achievement in relation to intelligence of class VII students. Excellence International Journal of Education and Research (Multi-subject Journal), 3, 239-245.

Astalini, A., Kurniawan, D. A., \& Putri, A. D. (2018). Identifikasi sikap implikasi sosial dari IPA, ketertarikan menambah waktu belajar IPA, dan ketertarikan berkarir dibidang IPA siswa SMP se-kabupaten Muaro Jambi. Tarbiyah: Jurnal Ilmiah Kependidikan, 7(2).

Astuti, S. P. (2015). Pengaruh kemampuan awal dan minat belajar terhadap prestasi belajar fisika. Formatif: Jurnal Ilmiah Pendidikan MIPA, 5(1).

Hartuti, P. M. (2015). Peran konsep diri, minat dan kebiasaan belajar peserta didik terhadap prestasi belajar fisika. Formatif: Jurnal Ilmiah Pendidikan MIPA, 5(2).

Juniati, N. W., \& Widiana, I. W. (2017). Penerapan model pembelajaran inkuiri untuk meningkatkan hasil belajar IPA. Jurnal Ilmiah Sekolah Dasar, 1(1), 20-29.

Kpolovie, P. J., Joe, A. I., \& Okoto, T. (2014). Academic achievement prediction: Role of interest in learning and attitude towards school. International Journal of Humanities Social Sciences and Education (IJHSSE), 1(11), 73-100.

Lawrence, A. S., \& Vimala, A. (2012). School Environment and Academic Achievement of Standard IX Students. Online Submission, 2(3), 210-215.

Mahyudi, S. (2012). Peranan Gaya Mengajar Guru Fisika Terhadap Minat Belajar Fisika Siswa Kelas IX MTs Istiqlal Delitua. Jurnal Pendidikan Fisika, 1(1), 9-14.

Mulyani, D. (2013). Hubungan kesiapan belajar siswa dengan prestasi belajar. Konselor, 2(1). 
Parasamya, C. E., Wahyuni, A., \& Hamid, A. (2017). Upaya peningkatan hasil belajar fisika siswa melalui penerapan model pembelajaran problem based learning (PBL). Jurnal ilmiah mahasiswa pendidikan fisika, 2(1), 42-49.

Putra, D. S., Lumbantoruan, A., \& Samosir, S. C. (2019). Deskripsi sikap siswa: adopsi sikap ilmiah, ketertarikan memperbanyak waktu belajar fisika dan ketertarikan berkarir di bidang Fisika. Tarbiyah: jurnal ilmiah kependidikan, 8(2), 91-100.

Putri, R. H., Lesmono, A. D., \& Aristya, P. D. (2017). Pengaruh model discovery learning terhadap minat belajar dan hasil belajar fisika siswa man bondowoso. Jurnal Pembelajaran Fisika, 6(2), 173-180.

Rochiati Wiriaatmadja, 2008. Metode Penelitian Tindakan Kelas.

Syarif, I. (2012). Pengaruh model blended learning terhadap minat dan prestasi belajar siswa SMK. Jurnal pendidikan vokasi, 2(2).

Setyawan, D. N., \& Edie, S. S. (2013). Implementasi Pendekatan Multiple Intelligences dalam Metode Praktikum untuk Melihat Peningkatan Keterampilan Proses Sains Siswa SMA. UPEJ Unnes Physics Education Journal, 2(3).

Zulkarnain, I. (2020). Pengaruh kemampuan awal terhadap prestasi belajar matematika siswa. Jurnal Ilmu Pendidikan (JIP) STKIP Kusuma Negara Jakarta, 11(2), 88-94. 